\title{
HISTOPATHOLOGICAL AND BIOCHEMICAL EFFECTS OF IMIPRAMINE ON LIVER, KIDNEY AND BRAIN IN ADULT MICE
}

\author{
SIHAM A. WADI \\ Department of Pharmacology- Collage of Veterinary Medicine University of Tikrit
}

Received: 28 March 2018; Accepted: 15 April 2018

\begin{abstract}
This study examined the hepatic functions (Aspartate aminotransferase (AST), alanine aminotransferase (ALT) and alkaline phosphatase (ALP)), and histological changes in liver and kidney in imipramine -induced rabbits. Twenty adult mice were randomly divided into two groups comprising 10 mice each. Control group, received $1 \mathrm{ml}$ normal saline $0.9 \%$. Groups 2 received daily, $10 \mathrm{mg} / \mathrm{kg}$ of Imipramine for 21 days. Assessment of (AST, ALT, and ALP) were done by spectrophotometry, in addition to histological studies. There were significant changes in parameters for rabbits in group 2 compared to control group. The histopathological examination of renal tissue revealed lymphocyte infiltration, congestion, glomerulus and tubular damage. The tubular was containing hypertrophied epithelial cell which block the lumen. Brain tissues in groups 2 showed degeneration of pyramidal cells in the cortex, congestion of the blood vessels in the cortex and medulla. The cortex certain pyramidal cell with slight enlarged. Conclusion: Evidence of biochemical and histopath-ological affection of hepatic, renal and brain evoked by repeated administration of imipramine for long periods.
\end{abstract}

Key words: Imipramine, Brain, Histology, Alkaline Phosphatase.

\section{INTRODUCTION}

Antidepressants are drugs that relieve the symptoms of depression. Imipramine is a commonly used prototype of a class of tricyclic antidepressants known as the TCAs. TCAs exert their effects by selectively blocking the reuptake of serotonin (5-HT) and norepinephrine (NE) in neurons, at presynaptic CNS nerve terminals, resulting in increased levels of both serotonin and norepinephrine in the synaptic cleft. The increased availability of neurotransmitter to the post synaptic neurotransmitter receptors is believed to account for the antidepressant activity of these agents. These agents also have multiple effects at other receptors, including antimuscarinic, $\alpha-$ adrenergic receptor and cardiac tissue. TCAs are considered very dangerous in overdose with significant antimuscarinic activity, cardiac dysrhythmias, and seizures being the most problematic. Imipramine used in the treatment of various forms of psychiatric disorders including depression, obsessive-compulsive disorder, panic attacks, and social phobias (Kocsis et al., 1988; Josephy, 2003 and Berkman et al., 2003).

The present study aimed to explain the histological changes in liver kidney and brainbiochemical parameters in imipramine -induced mice.

Corresponding author: Dr. SIHAM .A. WADI

E-mail address: sihamwadee@tu.edu.iq

Present address: Department of Pharmacology-Collage of

Veterinary Medicine University of Tikrit

\section{MATERIALS AND METHODS}

The experimental study was carried out on 20 mice during the period from June to May 2016, it has been achieved in the Animal House of the College of Veterinary Medicine / Tikrit University. The animals were maintained under controlled environmental conditions. They were provided a free access to standard pellet diet and tap water. The animals were divided into 2 groups each group consists of 10 animals:

Group 1 (G1): Healthycontrol mice.

Group 2 (G2): Mice receivedofImipramine10 mg/kg of was injected, intramuscularly.

\section{Histological study}

After sacrifice, livers, brain and kidney were obtained from the mice and immediately fixed in $10 \%$ formalin. The tissues excised and covered with physiological normal saline and cleaned from attached fat and connective tissue. Blocks of tissues were immediately fixed in $10 \%$ neutral buffered formalin, dehydrated with gradedseries of ethyl alcohol and embedded in paraffin. Photomicrographs of the stained with hematoxylin and eosin (H\&E), slides were taken using digital camera attached to light microscope (Buthayna et al., 2017).

\section{Biochemical Study:}

Blood samples were collected in dry centrifuge tubes for serum preparation, sera were separated and preserved at $-20^{\circ} \mathrm{C}$ till used for biochemical analysis to detect AST, ALT, and ALPlevels. 
Aspartate aminotransferase (AST) and alanine aminotransferase (ALT) were determined as described by Reitman and Frankel, using Randox Diagnostickit. (Reitman, 1957). The Estimation of
ALP was done by the methods as proposed by King (Kind, 1954).

Data were analyzed statistically by SPSS 21, using paired t-test and Pearson's correlation coefficient. Statistical significance was defined at $\mathrm{P}<0.05$.

\section{RESULTS}

The results of the study are presented in the table and figures below.

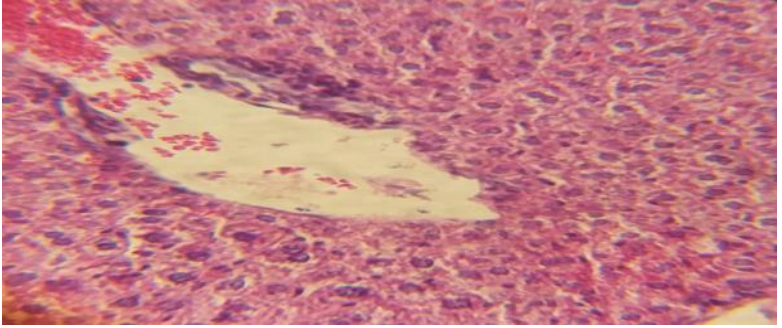

Figure 1: Light photomicrograph of sections from liver of rat administered with imipramine $10 \mathrm{mg} / \mathrm{kg}$, presented atrophy of liver cell was seen. The lymphocytic local aggregation. There was hemolysis of blood RBC in certain B.V.

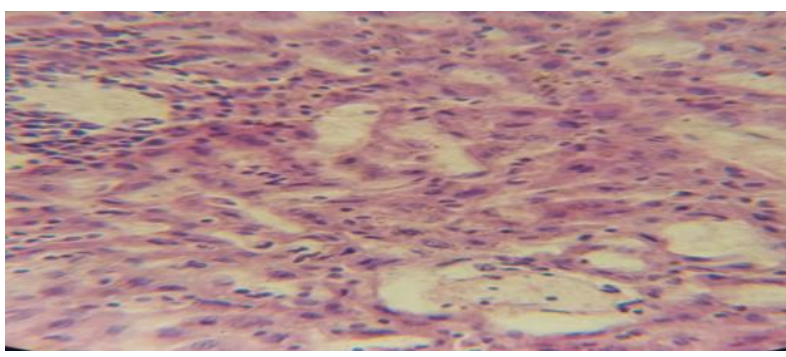

Figure 3: Light photomicrograph of sections from kidney of mice administered with imipramine $10 \mathrm{mg} / \mathrm{kg}$, Presented:atrophy of the certain glomeruli, glomerular damage and tubular damage, lymphocyte infiltration.

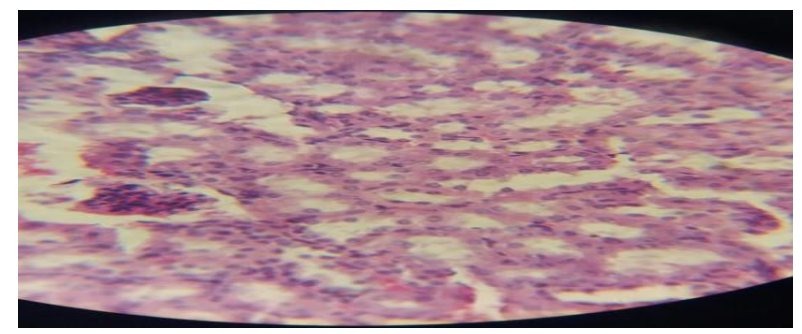

Figure 5: Light photomicrograph of sections from kidney of mice administered with Imipramine $10 \mathrm{mg} / \mathrm{kg}$, showed glomerulus damage and tubular damage, lymphocytes infiltration.

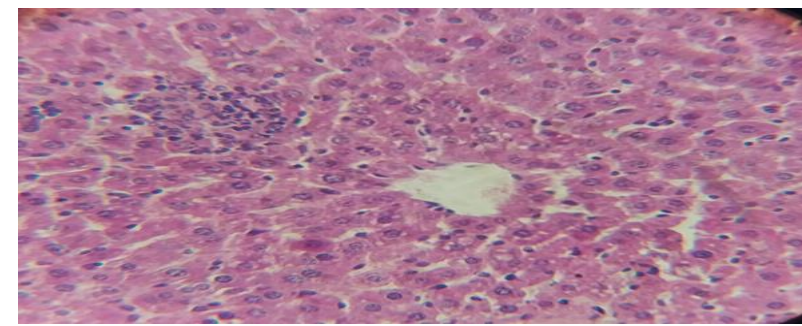

Figure 2: Light photomicrograph of sections from liver of mice administered with imipramine $10 \mathrm{mg} / \mathrm{kg}$. indicated local aggregation lymphocytes. Cells hepatocytes were enlarged and degenerated, necrotic change of the hepatocytes.

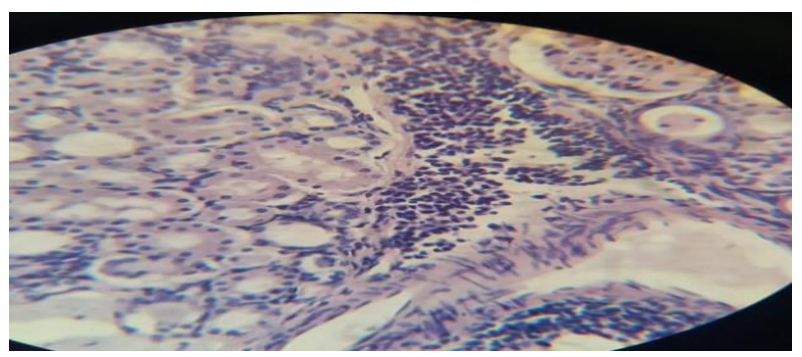

Figure 4: Light photomicrograph of sections from kidney of mice administered with imipramine $10 \mathrm{mg} / \mathrm{kg}$, Indicated the cortex was containing aggregation of lymphocytes (local and interstitial), The epithelial cells that linins the P.CI and H.C.T were hypertrophy And lose number of epithelia cells.

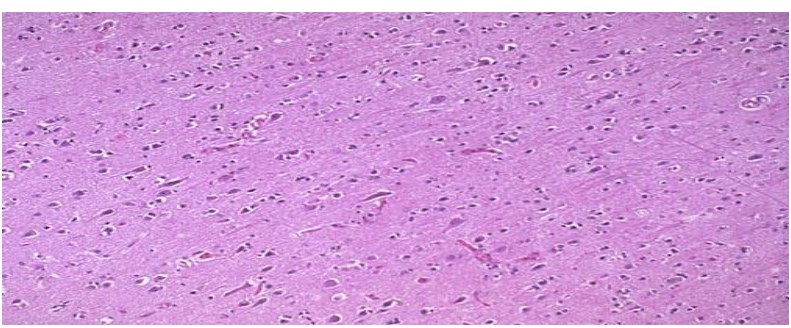

Figure 6: Light photomicrograph of sections from brain of G1.

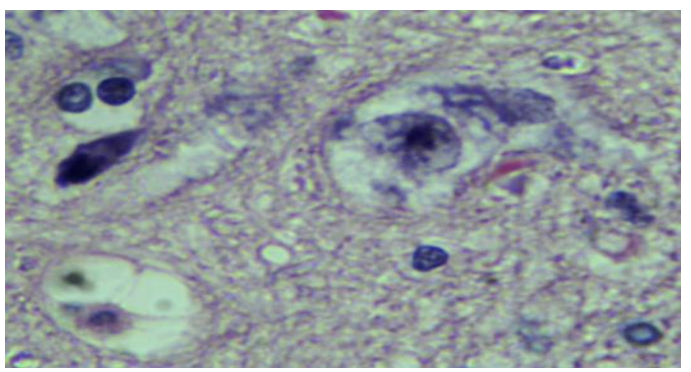

Figure 7: Light photomicrograph of sections from brain of mice administered with Imipramine $10 \mathrm{mg} / \mathrm{kg}$, displayed, tissues was containing congestion of the blood vessels in the cortex and medulla (white matter). The cortex certain pyramidal cell with slight enlarged. 
Table1: Effects of Imipramine on liver enzymes (AST, ALT, \& ALP) in adult mice.

\begin{tabular}{lcc}
\hline Parameters & Group 1 & Group 2 \\
\hline ALT (U/L) & $29.46 \pm 3.91$ & $34.98 \pm 2.62^{*}$ \\
\hline AST (U/L) & $35.8 \pm 21.5$ & $83.1 \pm 1.9^{* * *}$ \\
\hline ALP (U/L) & $66.18 \pm 1.3$ & $78.34 \pm 1.92^{*}$ \\
\hline
\end{tabular}

* Results represent mean \pm standard deviation of group serum results obtained.P $<0.05, * * \mathrm{P}<0.001$.

The data revealed that there is significant increase in serum ALT $(34.98 \pm 2.62 \mathrm{U} / \mathrm{L}, \mathrm{P}<0.05)$, ALP $(78.34$ $\pm 1.92 \mathrm{U} / \mathrm{L}, \mathrm{P}<0.05), \&$ AST $(83.1 \pm 1.9 \mathrm{U} / \mathrm{L}, \mathrm{P}<0.001$. $)$ in group 2 when compared with the control group $(29.46 \pm 3.91 \mathrm{U} / \mathrm{L}),(35.8 \pm 21.5 \mathrm{U} / \mathrm{L})$ and $(66.18 \pm$ $1.3 \mathrm{U} / \mathrm{L})$, respectively.

\section{DISCUSSION}

The liver histopathological effects of Imipraminetoxicity in the current study were supported by the liver function indices results. There were highly significant increase in serum AST, ALT, alkaline phosphatase enzyme levels in group II when compared with group I.

These results were comparable with the findings of Halpin and Yamamoto (2012) who reported suggest that imipramine is capable of producing hepatocellular damage that persists for $24 \mathrm{~h}$ after drug exposure, that in turn, contributes to the neurotoxicity of the drug.

Alkaline Phosphatase ALP enzyme present in cell surface in most human tissues. The highest concentration is found in the intestine, liver, bone, spleen and kidney (Gitnick, 1992, Sebnem, 1999). The specific location of the enzyme with both sinusoidal and bile canalicular membranes accounts for the more predominant elevations in certain disorders as observed in the present study with Imipramine administration. Impaired secretion of hepatic ALP may be accompanied by acute cell necrosis, so liberation of ALP in the circulation is elevated. The cellular injury may still persist as indicated by increased AST, ALT, ALP and bilirubin activities. The findings of the current investigation were in agreement with those of Zalis EG et al. (1967). And Entedhar, R. (2017) who reported that the levels of ALT, AST, ALP and bilirubin were significantly higher in rats exposed to acute and gradual increasing doses of Imipramine till reaching dependency when compared to the control group. The increase in plasma AST and ALT levels could reflect an effect of Imipramine on the plasma membrane of cells in the organ.

Studying of the histopathological effects of Imipramine on kidney and liver tissues of group II revealed glomerular hemorrhage, and atrophied glomeruli with collapsed tufts, wide Bowman's space, degenerated tubules and cellular infiltration, whereas local aggregation lymphocytes. Cells hepatocytes were enlarged and degenerated, necrotic change of the hepatocytes when compared with control group I.

This could be explained by the toxicokinetics process of Imipramine since the drug is metabolized in liver and excreted through the kidney in an unchanged manner. While the rest are changed into active metabolites by the liver. Metabolites of the drug that are excreted via kidneys may also cause cellular damage leading to hepatotoxicity and nephrotoxicity. This result is disagree with the report of Habib et al. (2015).

Imipramine-induced neurotoxicity involves the decreased nitric oxide concentration and nitric oxide synthase activity in brainproduction of brain ammonia, and suppressed microglial NADPH oxidase activation and decreased reactive oxygen species generation and oxidative stress (Bortolato, 2008, and LIU, 2011).

\section{REFERENCES}

Berkman, L.F.; Blumenthal, J.; Burg, M.; Carnew, R.M.; Catellier, D. and Cowan, M.J. (2003): "Effects of treating depression and low perceived social support on clinical events after myocardial infarction: the enhancing recovery in coronary heart disease patients (ENRICHD) randomized trial". Journal of The American Medical Association, 289: 31063116.

Bortolato, M.; Chen, K. and Shih, JC. (2008): Monoamine oxidase inactivation: from pathophysiology to therapeutics. Adv Drug Deliv Rev; 60: 1527-33.

Buthayna, A.; Abdulla, Entedhar R. Sarhat and Siham A. Wadi. (2017): Study Of The Effect Of Castor Seeds (Ricinus Communis Linn.) On Ovary Functions and Characters of Female Rabbits. Assiut Vet. Med. J. Vol. 63 No. 152 January 2017, 62-65.

Entedhar R. Sarhat; Siham A. Wadi and Saba K. Ibrahim (2016): The Influence of Lycopene on Interleukin-6, Tumor Necrosis Factor $-\alpha$, Alanine Aminotransferase, Aspartate Aminotransferase Levels In Stereptozotocin Induced Diabetic Rabbits. 3rd Scientific Conference - College of Veterinary Medicine University of Tikrit; 1-5. 
Gitnick, G. and Labrecque, Moody, F. (1992): Diseases of the liver and billiary tract. Mosbyyear book.

Habib, M.; Shaker, S.; El-Gayar, N. and AboulFotouh, S. (2015): The Effects of Antidepressants "Fluoxetine and Imipramine" on Vascular Abnormalities and Toll Like Receptor-4 Expression in Diabetic and NonDiabetic Rats Exposed to Chronic Stress. Resstel LBM, ed. PLoS ONE. 2015; 10(3): e0120559.

Halpin, LE.; Gunning, WT. and Yamamoto, BK. (2013): Methamphetamine causes acute hyperthermia-dependent liver damage. Pharmacology Research \& Perspectives; 1(1).

Josephy, A.L. (2003): "History of the use of antidepressants in primary care, primary care companion”. J. clin. Pysychiatry, 5(7):6-10.

Kind PRN; King EJ . J. Clin. Pathol. (1954): 7: 322.
Kocsis, J.H.; Frances, A.J.; Voss, C.; Mann, J.J.; Mason, B.J. and Sweeney, J. (1988): Imipramine treatment for chronic depression. Arch. Gen. Psychiatry 45, 253-257.

Liu, D.; Wang, Z.; Liu, S.; Wang, F.; Zhao S. and Hao, A. (2011): Antiinflammatory effects of fluoxetine in lipopolysaccharide (LPS)stimulated microglial cells. Neuropharmacology; 61: 592-599.

Reitman, S. and S. Frankel, Am. J. Clin. Pathol. (1957: 28: 56-62.

Sebnem, DW. And Handerson, AR. (1999): Clinical Enzymology in: Burtis CA. and Ashwood FR. Editors. Tietz Textbook of clinical chemistry (3rd edition), W.B. Saunders Company, Philadelphia.

Zalis, EG.; Lundberg, GD. and Knutson, RA. (1967): The pathophysiology of acute amphetamine poisoning with pathologic correlation. J. Pharmacol Exp Ther 158: 115-127.

\title{
الآثار المرضية والبيو كيميائية لأيمييرامين على الكبا والكلى والاماغ في الفئران
}

\author{
قسم الادوية و الكيماء الحياتية و الفسئلجة - كلية الطب البيطري \\ E-mail: sihamwadee@tu.edu.iq Assiut University web-site: www.aun.edu.eg
}

فحصت هذه الدر اسة الوظائف الكبدية (أسبارتيت أمبينو تر انسفريز) (AST))، ألنين أمبين ترانسفريز (ALT) وفوسفاتيز القاعدي

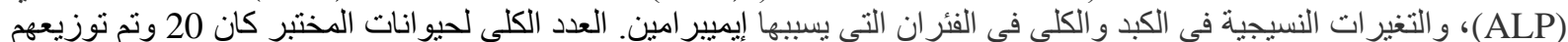

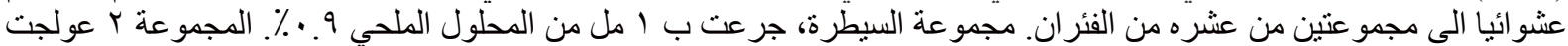
يوميا، ب • ( ملغ / كغ من إيميبر امين لمدة ال يوما. تم تقييم (أسبارتيت أمينو تر انسفريز ، ألنين أمينو تر انسفريز وفوسفاتيز القاعدي)

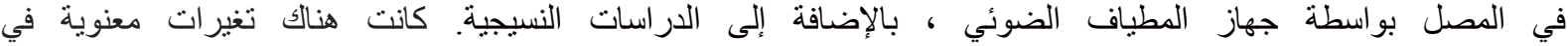

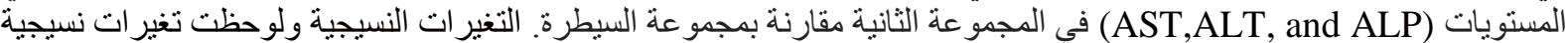

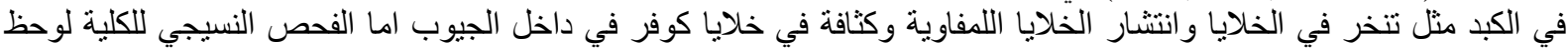

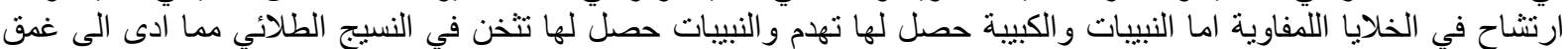

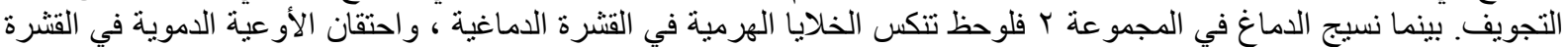

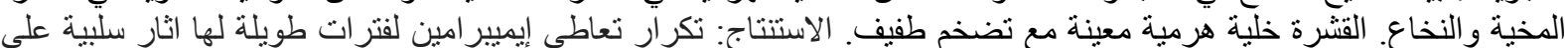

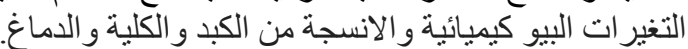

